\title{
AGROTEKNIKA
}

www.agroteknika.id

\section{Rancang Bangun Pendeteksi Curah Hujan Menggunakan Tipping Bucket Rain Sensor dan Arduino Uno}

\section{Design and Building of Precipitation Detector Device Base on Tipping Bucket Rain Sensor and Arduino Uno}

\author{
Muhammad Syahbeni ${ }^{1}$, Arif Budiman ${ }^{1}$, Rosda Syelly ${ }^{*}, 1$, Indra Laksmana ${ }^{2}$, Hendra $^{2}$ \\ ${ }^{1}$ Program Studi D3 Teknik Komputer, Sekolah Tinggi Teknologi Payakumbuh \\ ${ }^{2}$ Program Studi Mesin dan Peralatan Pertanian, Politeknik Pertanian Negeri Payakumbuh
}

\author{
${ }^{*}$ Penulis Korespondensi \\ Email: rosdasyelly@gmail.com
}

\begin{abstract}
Abstrak. Curah hujan merupakan salah satu parameter hujan yang dapat diukur. Curah hujan dinyatakan dengan seberapa besar tinggi air yang ditimbulkan oleh hujan di suatu daerah. Penakar Curah Hujan adalah alat untuk mengukur jumlah curah hujan yang turun kepermukaan tanah dengan membandingkannya dengan per satuan luas. Curah hujan 1 (satu) milimeter, maksudnya adalah daerah datar dengan luas satu meter persegi tertampung air setinggi 1 (satu) milimeter atau tertampung air sebanyak 1 (satu) liter atau $1000 \mathrm{ml}$. Salah satu sistem penakar hujan adalah tipping bucket. Penakar hujan Tipping Bucket mempunyai luas permukaan corongnya beragam sperti: $0.1 \mathrm{~mm}, 0.2 \mathrm{~mm}, 0.5 \mathrm{~mm}$ dan lain-lain. Penelitian ini resolusi Tipping Bucket yang digunakan ialah $0.2 \mathrm{~mm}$, dan juga memakai Modul Sensor Reed Switch. Reed Switch akan bekerja ketika magnet yang di tempel pada bagian tengah Tipping Bucket mendekati sensor Reed Switch, yang dimana Tipping Bucket akan bergerak disaat curah hujan masuk ke dalam corong dan akan ditampung pada Tipping Bucket yang membuat Tipping Bucket akan berjungkit. Kemudian Reed Switch akan mendeteksi magnet yang ada pada Tipping Bucket. Mikrokontroler berfungsi untuk membaca data dari Modul Sensor Reed Switch yang tiap kali ada sentuhan dari magnet.
\end{abstract}

Kata Kunci: tipping bucket, arduino uno, modul sensor reed switch

\begin{abstract}
Precipitation is one parameter of rain that can be measured. Where rainfall states how much water is generated by rain in an area. An equipment to measure the amount of rainfall that falls on the surface of the land per unit area called the Precipitation Gauge. One milimeter precipitation, means that in an area of one square meter in a flat place accommodated by water as high as 1 (one) millimeter or accommodated as much as 1 (one) liter or $1000 \mathrm{ml}$ of water. For Raindrops Tipping Bucket, the rainfall value of each bucket tipping is not the same, and the funnel surface area varies, for example, there is $0.1 \mathrm{~mm}, 0.2 \mathrm{~mm}, 0.5 \mathrm{~mm}$ and others. In designing this tool the Tipping Bucket resolution used is $0.2 \mathrm{~mm}$ and also uses the Reed Switch Sensor Module. Reed Switch will work when the magnet attached to the center of the Tipping Bucket approaches the sensor of the Reed Switch, where Tipping Bucket will move when rainfall enters the funnel and will be accommodated in Tipping Buckets which will cause Tipping Bucket to topple. Then the Reed Switch will detect the magnet in Tipping Bucket. The microcontroller has functions to read data from the Reed Switch Sensor Module, when there is a touch of the magnet.
\end{abstract}

Keywords: tipping bucket, arduino uno, sensor reed switch module 


\section{Pendahuluan}

Hujan adalah hydrometeor yang jatuh berupa partikel-partikel air yang mempunyai diameter $0.5 \mathrm{~mm}$ atau lebih. Hujan disebut juga hydrometeor yang jatuh ke tanah disebut hujan sedangkan yang tidak sampai tanah disebut Virga (Tjasyono, 2006). Salah satu unsur cuaca yang datanya diperoleh dengan cara mengukurnya dengan menggunakan alat penakar hujan dalam satuan millimeter (mm) adalah curah hujan. Curah hujan sebesar $1 \mathrm{~mm}$ merupakan jumlah air hujan yang jatuh di permukaan per satuan luas ( $\mathrm{m} 2$ ) dengan tinggi $1 \mathrm{~mm}$ dengan syarat tidak ada yang meresap, menguap atau mengalir. Berarti, curah hujan sebesar $1 \mathrm{~mm}$ sama dengan 1 liter/ m2 ( Aldrian et al, 2011). Pengukur curah hujan yang telah dikembangkan diantaranya jenis weighing, kapasitansi, tipping-bucket (TB), optik, dan lain-lain (Brock \& Richardson (2001) dan Mansheim et al (2010)) . Penakar hujan tipe tipping bucket, nilai curah hujannya tiap bucket berjungkit tidak sama, serta luas permukaan corongnya beragam, Misalnya ada yang 0.1 $\mathrm{mm}, 0.2 \mathrm{~mm}, 0.5 \mathrm{~mm}$ dan lain-lain. Evita et al (2010) telah membuat alat ukur curah hujan tipping-bucket sederhana dan murah berbasis mikrokontroler. Novianta (2011) membuat sistem data logger curah hujan dengan model tipping bucket berbasis mikrokontroller. Muliantara (2015) membuat rancangan alat ukur ketinggian curah hujan otomatis berbasis mikrokontroler. Arifin \& Rahadian (2017) membuat rancang bangun stand-alone automatic rain gauge (arg) berbasis panel surya. Penelitian-penelitian tersebut telah menerapkan penakar hujan tipping bucket dan mikrokontroler sebagai komponen utama. Penelitian-penelitian tersebut masih banyak mempunya kelemahan diantaranya dari segi akurasi pengukuran.

Penelitian ini melakukan rancang bangun pendeteksi curah hujan menggunakan tipping bucket rain sensor dan arduino uno. Penelitian ini memanfaatkan mikrokontroler dan penakar hujan tipping bucket sebagai komponen utama. Mikrokontroler adalah suatu chip yang dapat diprogram sesuai dengan software yang kita buat. Pengunaan mikrokontroler pada penelitian ini sebagi control utama uang berfungsi untuk mengitung berapa kali tipping bucket terjungkit dalam satuan waktu.

\section{Bahan dan Metode}

Tahap ini membahas tentang perancangan sistem yang digunakan dari alat sistem tipping bucket rain sensor. Dalam membuat suatu sistem harus dilakukan analisa mengenai sistem yang akan dirancang. Pembuatan alat sistem tipping bucket membahas perancangan awal dimulai dari menentukan jenis sensor dan Mikrokontroler yang digunakan dan menentukan input dan output sebagai human interface. Berikut adalah bagian - bagian pada sistem tipping bucket yaitu: Sensor Reed Switch digunakan sebagai saklar penggerak ketika tipping bucket atau bejana terisi oleh air. Reed Switch atau disebut juga saklar listrik yang dioperasikan dengan medan magnet, yang terdiri dari sepasang kontak pada tubuh logam besi dalam tertutup rapat kaca amplop. 
Magnet sebagai penggerak atau penghubung sensor Reed Switch atau disebut juga penyambung saklar. Tipping Bucket atau bejana berguna untuk menampung air hujan yang masuk lewat corong kecil yang memiliki 2 ruang bucket. Mikrokontroler berfungsi untuk membaca data dari sensor Reed Switch yang tiap kali mendeteksi adanya gerakan dari magnet yang melekat pada bucket.

\section{Diagram Blok Sistem}

Blog diagram merupakan gambaran rangkaian yang terdiri dari beberapa blog yang saling berhubungan dan saling mendukung satu sama lainnya, sehingga membentuk satu kesatuan sistem secara umum. Blok diagram pada sistem ini dapat dilihat pada Gambar 1. Sensor Reed Switch, berfungsi untuk mengaktifkan atau menyambung saklar yang di aktifkan oleh magnet kemudian nantinya akan diproses oleh Mikrokontroler arduino uno. Mikrokontroler Arduino uno sebagai pengolah data dari keseluruhan sistem, bekerja dengan tegangan catu single suply 5 volt. Data yang sudah dikirim Arduino ke Personal Computer akan di proses oleh Bahasa Pemrograman Visual Studio.Net. Visual Studio.Net akan memproses data yang sudah didapat dan akan menampilkan nya pada layar Monitor.

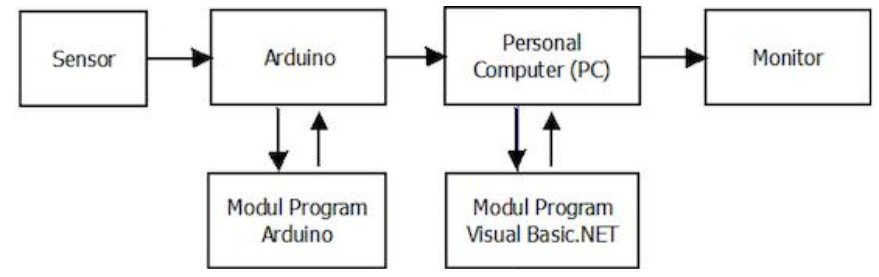

Gambar 1. Diagram Blok Sistem Secara Keseluruhan

\section{Rangkaian alat simulasi Menggunakan LED}

Alat yang dibuat bekerja secara otomatis tanpa ada kontrol dari user, sistem bekerja berdasarkan proses dari mikrokontroler arduino yang berbentuk logika biner dengan nilai yang telah ditentukan pada program, apabila nilai yang dimasukkan sesuai dengan yang ada pada program maka sistem akan berjalan.

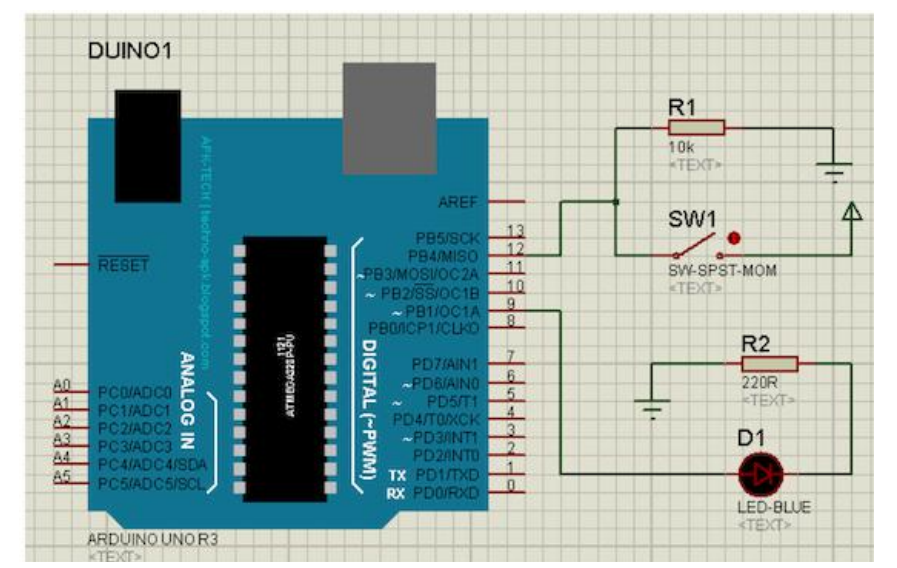

Gambar 2. Rangkaian alat simulasi menggunakan LED 
Cara kerja rangkaian pada Gambar 2 yaitu: Diantara R1 dengan Switch terhubung pada satu jalur pin 12 yang ada pada arduino, kemudian kaki R1 lainnya terhubung ke ground arduino dan kaki Switch lainnya terhubung pada power atau positif 5v arduino. Positif LED terhubung pada pin 9 arduino dan negatif LED terhubung pada R2 dan selanjutnya terhubung ke ground arduino. Ketika Switch di tekan maka LED akan hidup atau bernilai 1, ketika sebaliknya maka LED akan bernilai 0.

\section{Rangkaian Controller Sistem}

Arduino Uno mencakup pengontrolan mikrokontroler, sensor Reed Switch dan LED, menjadi satu modul pengontrolan. Putera (2015) telah menggunakan Arduino dalam mengukur suhu dan kelembaban udara pada hydroponic system. Rangkaian Controller Sistem dapat dilihat pada Gambar 3.

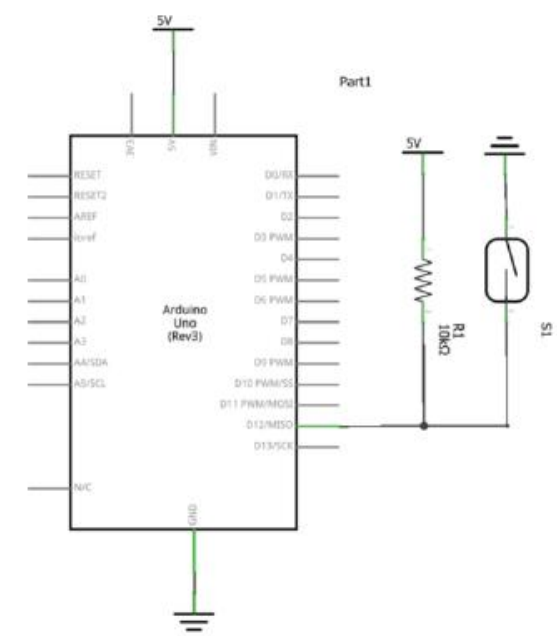

Gambar 3. Rangkaian Controler Arduino Uno

Pada pembuatan alat pendeteksi Curah Hujan ini digunakan Arduino Uno. Arduino merupakan Atmel family mikrocontroller yang menggunakan bahasa C sebagai bahasa pengontrolannya.

Mikrokontroler ini memiliki 14 pin input/output digital, 6 digunakan sebagai Pulse Width Modulation (PWM), 6 pin input analog yaitu pin A0-A5, tombol reset, dan pin header tengah. 6 pin header tersebut dapat dihubungkan ke kabel FTD1 untuk berkomunikasi dengan board. Arduino Uno ini memiliki beberapa fitur lain yaitu: Memiliki Static Random Access Memory (SRAM) sebesar 2 KB. 130 macam perintah yang hampir semuanya mampu dieksekusi dalam satu siklus clock. register serba guna sebanyak 32 x 8-bit. Memiliki Electrically Erasable Programmable Read Only Memory (EEPROM) sebesar $1 \mathrm{~KB}$ sebagai tempat penyimpanan data semi permanen sehingga dapat menyimpan data meskipun catu daya dipadamkan. Kecepatan mencapai 16 MIPS dengan clock $16 \mathrm{MHz} 32 \mathrm{~KB}$ Flash memory dan pada arduino memiliki boatloader yang menggunakan $2 \mathrm{~KB}$ dari flash memory sebagai boatloader. 


\section{Rangkaian Reed Switch Sensor}

Pada Gambar 4 dapat dilihat rangkaian sensor yang digunakan adalah sensor Reed Switch, dimana sensor ini sama dengan saklar cuma sensor ini di gerakkan oleh magnet. Ketika magnet mengarah pada sensor maka sensor bernilai, ketika sebaliknya sensor mati atau tidak tersambung.

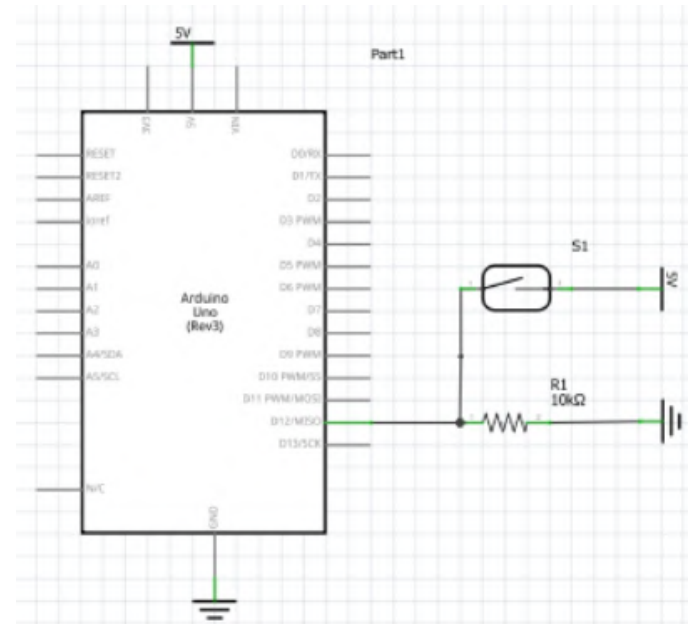

Gambar 4. Rangkaian Reed Switch Sensor

\section{Perancangan Perangkat Lunak}

Perancangan Perangkat Lunak yang digunakan pada penelitian ini adalah perancangan Aplikasi Pengukuran Curah Hujan dibuat menggunakan program Microsoft Visual Studio 2010 dengan tools Visual Basic.NET.

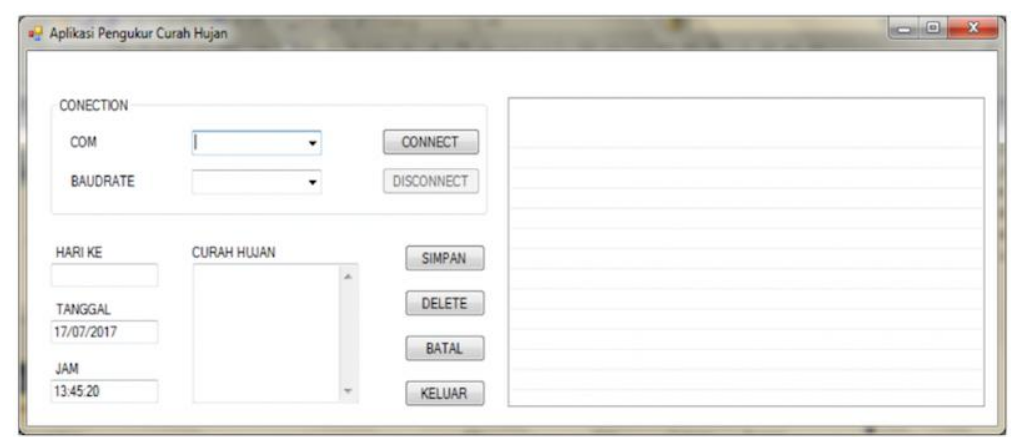

Gambar 5. Desain Aplikasi Pengukur Curah Hujan

Dalam perancangan desain Aplikasi VB.Net Toolbox yang di pakai ialah GroupBox, Label, Combobox, Button, ListView, TextBox, SerialPort dan Timer. Seperti yang terlihat pada Tabel 1 .

Tabel 1. Tabel Property VB.Net

\begin{tabular}{llc}
\hline Object & \multicolumn{2}{c}{ Property } \\
\hline Form_Curah_Hujan & Name & \\
GroupBox1 & Name & CONECTION \\
Label 1 & Name & COM \\
Label 2 & Name & BAUDRATE \\
Label 3 & Name & HARI KE \\
Label 4 & Name & TANGGAL \\
Label 5 & Name & JAM \\
\hline
\end{tabular}




\begin{tabular}{llc}
\hline Label 6 & Name & CURAH HUJAN \\
Combobox 1 & Name Caption & CmbPort \\
Combobox 2 & Name Caption & CmbBaud \\
Button 1 & Name Caption & CONNECT \\
Button 2 & Name Caption & DISCONNECT \\
Button 3 & Name Caption & SIMPAN \\
Button 4 & Name Caption & DELETE \\
Button 5 & Name Caption & BATAL \\
Button 6 & Name Caption & KELUAR \\
ListView 1 & View & Details \\
TextBox 1 & MultiLine & FALSE \\
TextBox 2 & MultiLine & FALSE \\
TextBox 3 & MultiLine & FALSE \\
TextBox 4 & MultiLine & TRUE \\
Timer & & \\
SerialPort 1 & & \\
\hline
\end{tabular}

\section{Flowchart Sistem}

Sebelum membuat pemrograman untuk protype ini, diawali dengan pembuatan flowchart terlebih dahulu. Adapun untuk flowchartnya sendiri adalah seperti ditunjukkan Gambar 6.

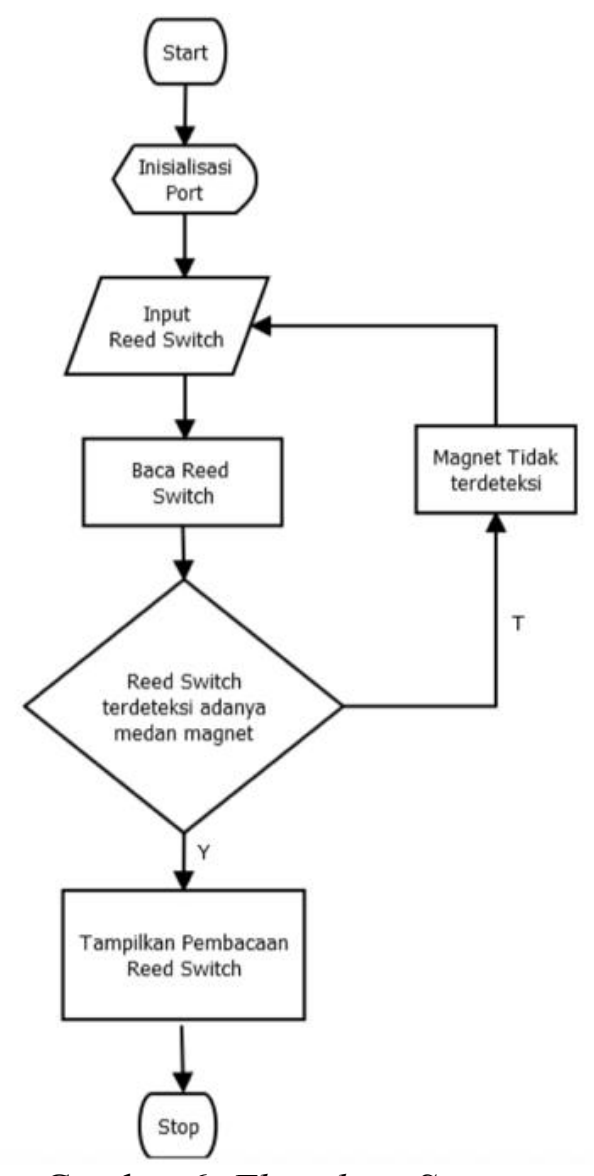

Gambar 6. Flowchart Sistem

\section{Alat dan Bahan}

Alat dan Bahan yang digunakan dalam penelitian ini dapat dilihat pada Tabel 2 dan 3. 
Tabel 2. Daftar alat yang digunakan

\begin{tabular}{ccc}
\hline No & Nama alat & Banyaknya \\
\hline 1 & Multimeter & $1 \mathrm{bh}$ \\
2 & Timah & $1 \mathrm{rol}$ \\
3 & Solder dan tinol & $1 \mathrm{bh}$ \\
4 & Bor DC & $1 \mathrm{bh}$ \\
5 & Mata bor 1 dan $3 \mathrm{~mm}$ & $1 \mathrm{bh}$ \\
6 & Gergaji besi & $1 \mathrm{bh}$ \\
7 & Tang & $1 \mathrm{bh}$ \\
\hline
\end{tabular}

Tabel 3. Daftar bahan yang digunakan

\begin{tabular}{cccc}
\hline No & Nama komponen & Jenis/Tipe & Banyaknya \\
\hline \multirow{2}{*}{1} & IC & Arduino Uno & 1 \\
2 & Resistor & Regulator Tegangan 5V 7805 & 1 \\
3 & Led & Merah & 1 \\
4 & Modul Sistem & Standart Sistem Minimum & 1 \\
& Minimum Arduino & Arduino Uno R3 & 1 \\
\hline
\end{tabular}

\section{Spesifikasi Sistem}

Spesifikasi dari sistem yang dirancang dapat dilihat pada Tabel 4.

Tabel 4. Daftar spesifikasi sistem

\begin{tabular}{llll}
\hline 1. & Tegangan Kerja & DC 5V & \\
2. & Tipe Sensor & Sensor Reed Switch & \\
3. & Tipe Mikrokontroler & $\begin{array}{l}\text { ATMEGA seri ATMEGA328 yang } \\
\text { kemasan arduino. }\end{array}$ & termasuk dalam \\
4. & Bahasa Pemrograman & Arduino, Visual Basic 2010 & \\
5. & Personal Computer & Komputer / Laptop & \\
\hline
\end{tabular}

\section{Hasil dan Pembahasan}

\section{Hasil}

Pada bab ini akan dibahas hasil pengujian dan pengamatan dari rancang bangun pendeteksi curah hujan menggunakan Tipping Bucket rain sensor dan arduino uno yang berfungsi untuk mengetahui apakah rancangan alat dan sistem yang telah direncanakan sudah bekerja dengan benar. Maka dilakukan pengujian dalam bentuk membuat rangkaian yang berguna untuk memudahkan dalam perancangan pembuatan alat. Serta hasil dari pengamatan alat juga berguna untuk mengetahui tingkat kinerja alat yang dibuat.

\section{Rangkaian Arduino}

Rangkaian arduino uno (Gambar 6) adalah rangkaian yang dibuat sebagai pusat pengendali dari rangkaian alat, hasil dari kerja alat akan ditampung dan di proses pada rangkaian arduino uno. Arduino menerima tegangan sebesar 5 Volt. Pin yang dipakai pada arduino uno tersebut ialah pin arus 5V, Ground, pin 12, pin tersebut ialah pin sambungan dari sensor Reed Switch dan juga pin 9 untuk rangkaian LED. 


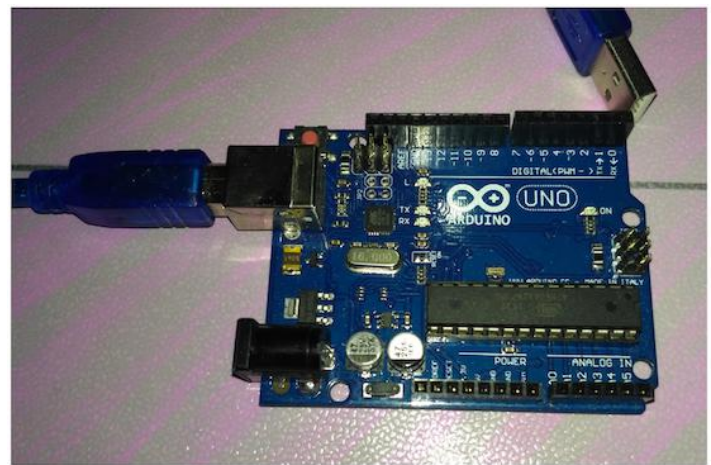

Gambar 6. Rangkaian Arduino Uno

\section{Rangkaian Sensor Reed Switch}

Rangkaian sensor Reed Switch (Gambar 7) ini berguna untuk menerima nilai Curah Hujan yang dihasilkan dari pengukuran agar bisa diteruskan dan diolah oleh arduino. Dan di sensor ini lah yang akan membaca berapa banya Curah Hujan yang dihasilkan.

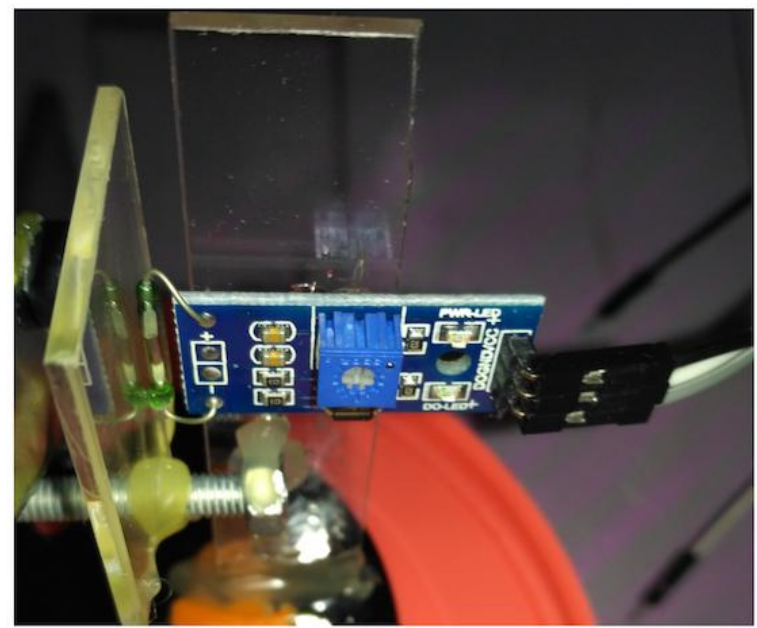

\section{Alat Tipping Bucket}

Gambar 7. Rangkaian Sensor Reed Switch

Tipping bucket (Gambar 8) ini berfungsi untuk menampung hujan yang masuk pada corong. Tipping Bucket ini akan berjungkit ketika penuh bagian kiri dan juga bagian kanan. Dan disini lah berapa besar curah hujan yang masuk pada Tipping Bucket tersebut.

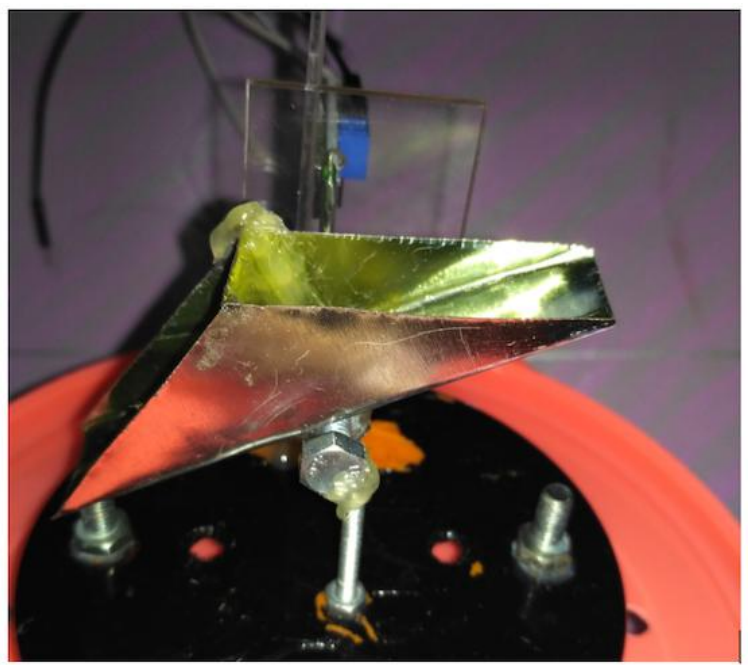

Gambar 8. Alat Tipping Bucket 


\section{Magnet}

Magnet (Gambar 9) di sini berfungsi sebagai penyambung dan pemutus Switch yang ada pada sensor Reed Switch. Ketika magnet sejajar dengan sensor maka sensor akan tersambung ketika sebaliknya maka sensor akan merenggang.

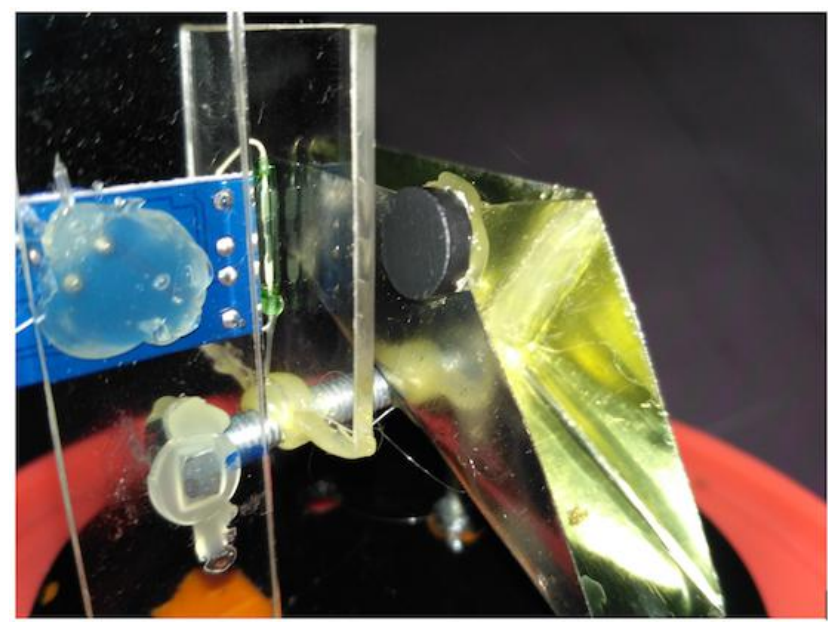

Gambar 9. Magnet pada Tipping Bucket

\section{Rangkaian alat Keseluruhan}

Hasil perancangan prototype pendeteksi curah hujan menggunakan tipping bucket rain sensor keseluruhan dapat dilihat pada Gambar 10.

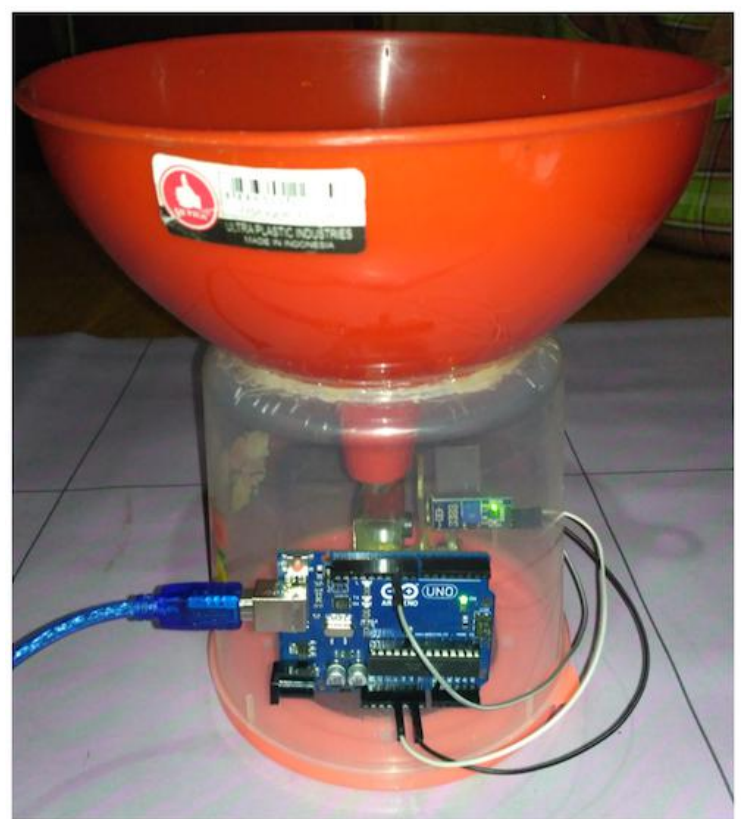

Gambar 10. Rangkaian Keseluruhan

\section{Cara kerja alat}

Reed Switch akan bekerja ketika magnet yang di tempel pada bagian tengah Tipping Bucket mendekati sensor Reed Switch, yang dimana Tipping Bucket akan bergerak disaat curah hujan masuk ke dalam corong dan akan ditampung pada Tipping Bucket yang membuat Tipping Bucket akan berjungkit. Kemudian Reed Switch akan mendeteksi magnet yang ada pada Tipping Bucket. 


\section{Rancangan Software Program Arduino IDE}

Alat ini menggunakan software Arduino IDE (Gambar 11) untuk membuat perintah ke alat agar bekerja. Dari program ini akan memerintahkan sensor untuk membaca besar kecilnya curah hujan yang ditampung oleh. Hasil pengujian program dapat dilihat pada Gambar 12.

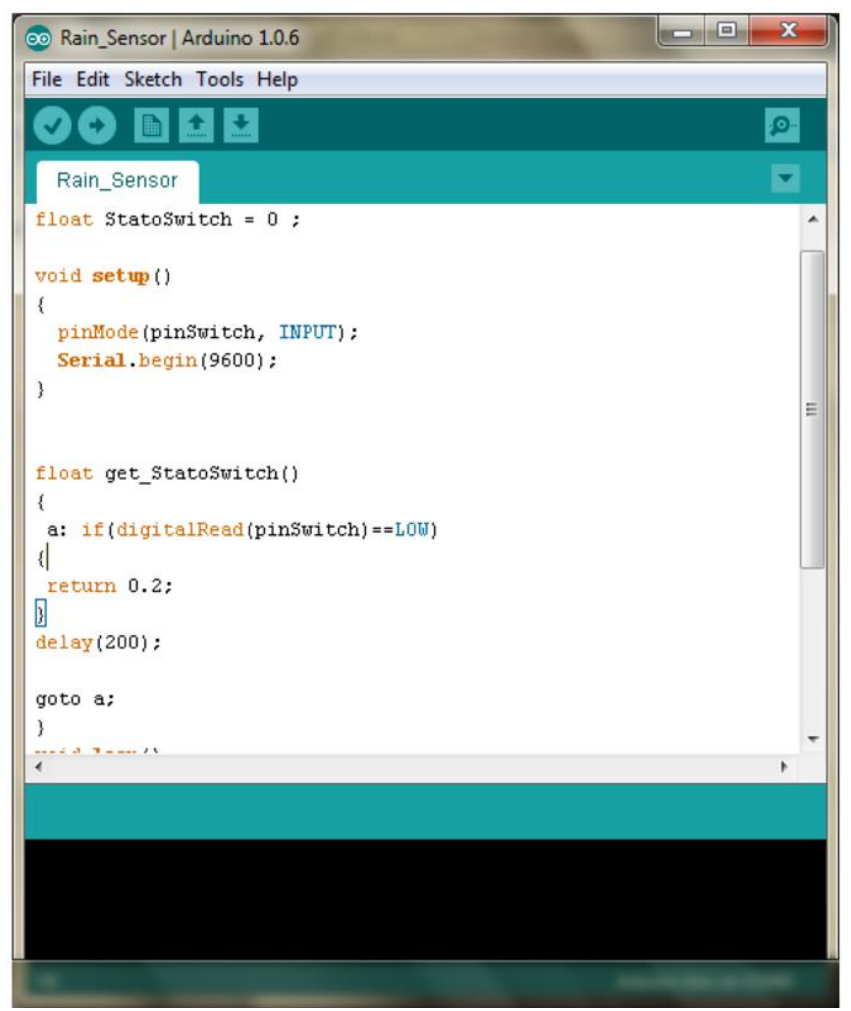

Gambar 11. Listing Program Arduino IDE

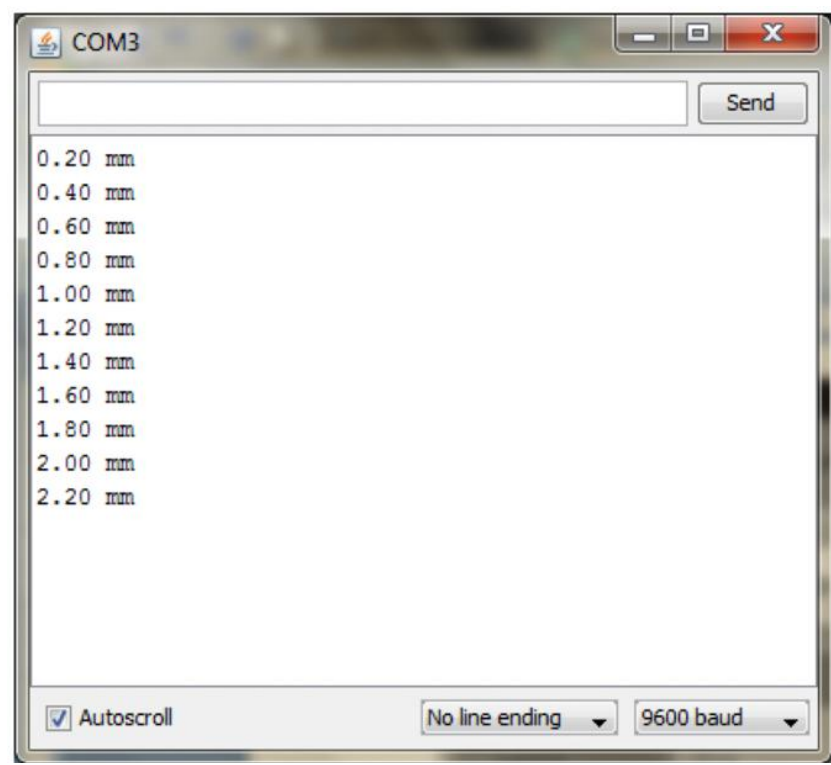

Gambar 12. Hasil dari Program Arduino IDE

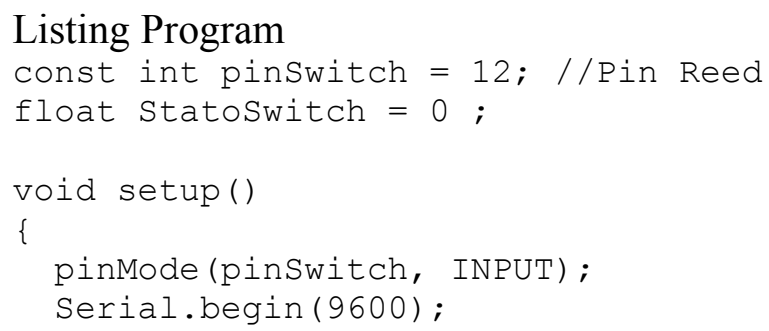




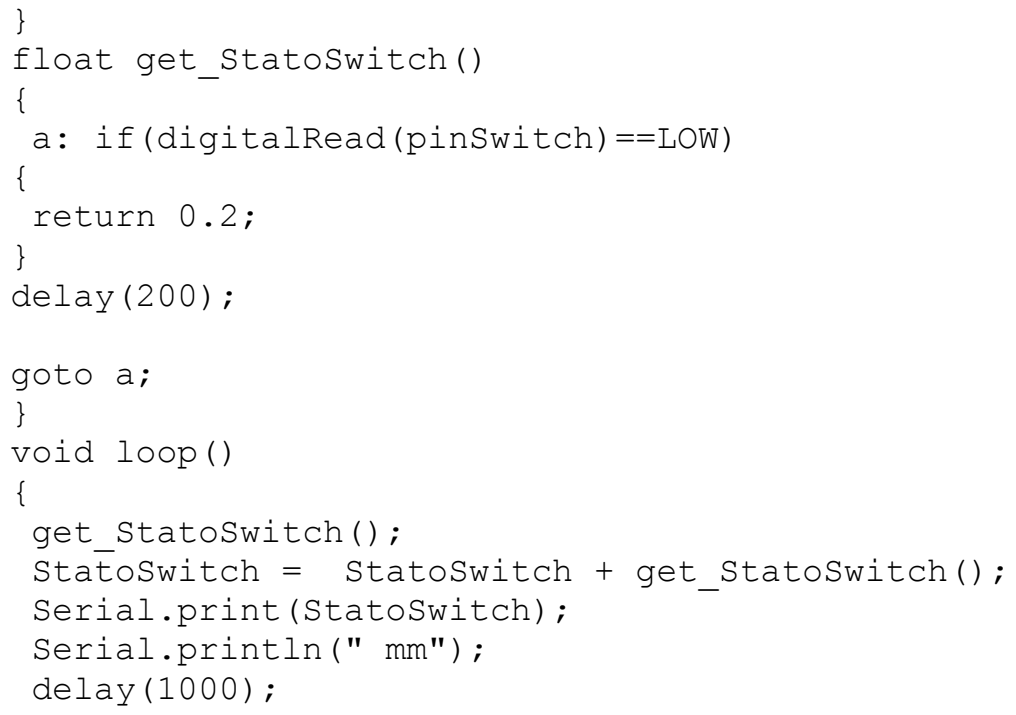

\section{Rancangan Program Visual Basic.Net}

Untuk menampilkan data yang sudah didapat dari sensor yang dikirim ke Arduino. Data yang sudah ditampung di Arduino langsung dikirim ke Visual Basic.Net yang terhubung melalui dari Serial Port kemudian data yang didapat ditampilkan di monitor. Form pengukur curah hujan (Gambar 13) ini berfungsi untuk menampilkan hasil dari pengukuran Curah hujan yang di proses oleh Arduino IDE, hasil curah hujan didapat dari sensor Reed Switch.

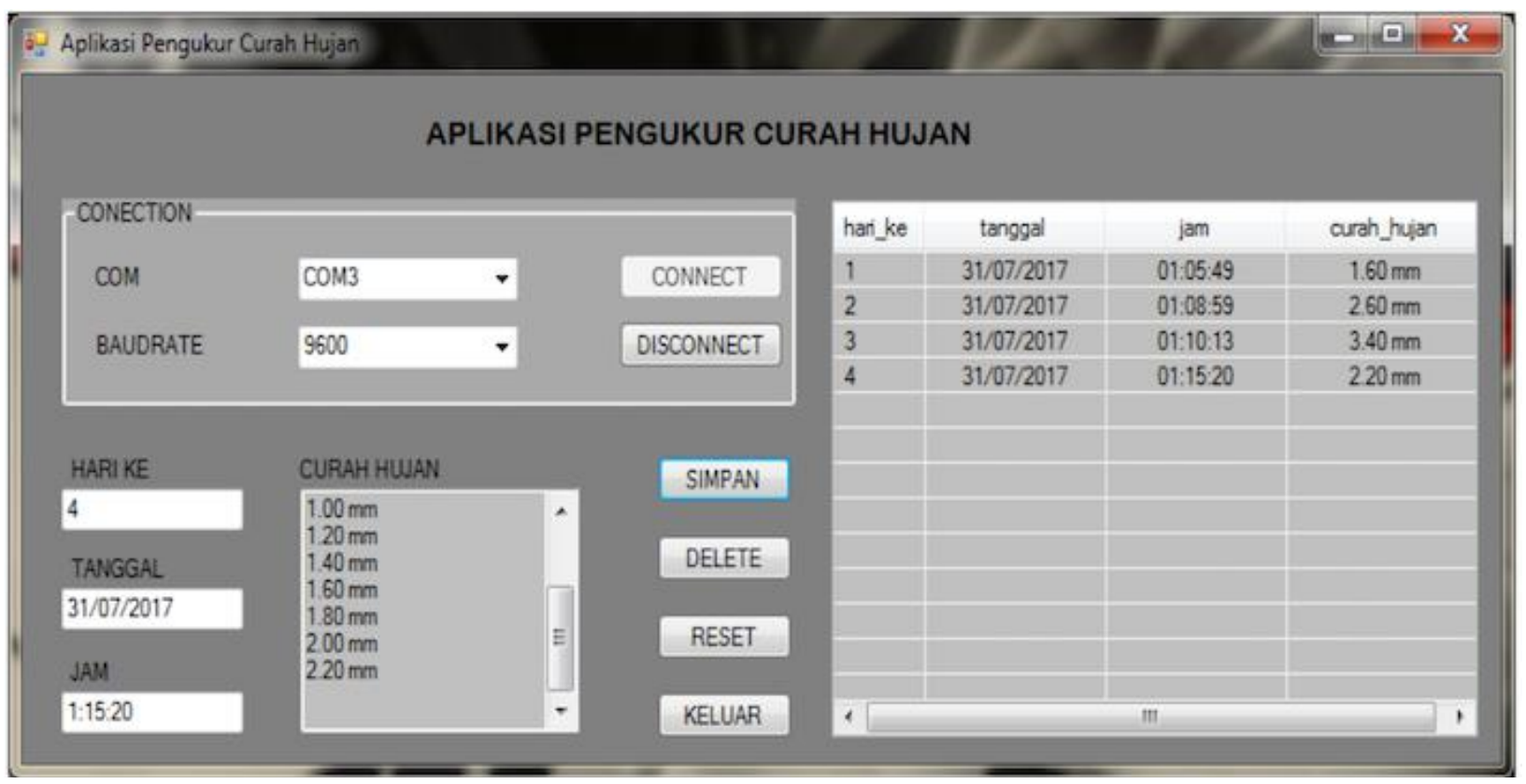

Gambar 13. Tampilan form Aplikasi Pengukuran Curah Hujan

\section{Kesimpulan}

Data hasil dari curah hujan di ambil dari berapa penampang bucket yang di kalibrasikan. Sensor Curah Hujan yang dipakai ialah Sensor Module Reed Switch. Reed Switch akan bekerja ketika magnet yang di tempel pada bagian tengah Tipping Bucket mendekati sensor Reed Switch, yang dimana Tipping Bucket akan bergerak disaat curah hujan masuk ke dalam corong dan akan ditampung pada Tipping Bucket yang membuat Tipping Bucket akan berjungkit. Perangkat lunak 
dari sistem yang dibuat (Arduino Uno) dapat mengatur dan menentukan langkah-langkah yang harus dilakukan mikrokontroler pada keseluruhan sistem yang dibuat.

\section{Daftar Pustaka}

Aldrian, E., Budiman, \& Karmini M. (2011). Adaptasi dan Mitigasi Perubahan Iklim di Jakarta. Pusat Perubahan Iklim dan Kualitas Udara Kedeputian Bidang Klimatologi, Badan Meteorologi, Klimatologi dan Geofisika. Jakarta.

Arifin, Z., \& Rahadian, H. (2017) Rancang Bangun Stand-Alone Automatic Rain Gauge (Arg) Berbasis Panel Surya. Jurnal Nasional Teknik Elektro, 6(3), 178-184.

Brock, F. V., \& Richardson, S. J. (2001). Meteorological Measurement Systems. New York: Oxford Univ. Press.

Evita, M., Mahfudz, H., Suprijadi, Djamal, M., \& Khairurrijal. (2010). Alat Ukur Curah Hujan Tipping-Bucket Sederhana dan Murah Berbasis Mikrokontroler. Jurnal Otomasi Kontrol \& Instrumentasi, 2(2), 1-8.

Mansheim, T. J., Kruger, A., Niemeier, J., \& Brysiewicz, A. J. B. (2010). A Robust Microwave Rain Gauge. IEEE Trans. Instrum. Meas, 59, 2204-2210.

Muliantara, A., Sanjaya, E. R. N., \& Widiartha, I. (2015). Perancangan Alat Ukur Ketinggian Curah Hujan Otomatis Berbasis Mikrokontroler. Jurnal Ilmu Komputer, 8(2), 31-37.

Novianta, M. (2011). Sistem Data Logger Curah Hujan Dengan Model Tipping Bucket Berbasis Mikrokontroller. Jurnal Teknologi, 4(2), 160-166.

Putera, P., Novita, S. A., Laksmana, I., Hamid, M. I., \& Syafii, S. (2015). Development and Evaluation of Solar-Powered Instrument for Hydroponic System in Limapuluh Kota, Indonesia. International Journal on Advanced Science, Engineering and Information Technology, 5(5), 284-288.

Tjasyono, B.H.K. (2006). Ilmu Kebumian dan Antariksa. Bandung: PT. Remaja Rosdakarya bekerjasama dengan Program Pascasarjana UPI. 